\title{
OS DISCURSOS SOBRE A EMANCIPAÇÃO FEMININA PRODUZIDOS NA CIDADE DO RECIFE (1870-1909)
}

\author{
ALBUQUERQUE, Tereza Lopes ${ }^{1}$
}

\begin{abstract}
RESUMO
Na cidade do Recife, para a consecução de uma cidade civilizada, a mulher passou a ser peça importante na construção de uma cidade dentro dos propósitos da civilização, por isso a mulher foi moldada conforme o interesse de grupos sociais que as forjavam. Aliadas a esse desejo de progresso, as transformações urbanísticas ocorridas na cidade e suas consequências possibilitaram uma modificação do perfil da mulher na sociedade. Em diferentes momentos históricos nos oitocentos- apesar de setores conservadores da sociedade- nos jornais, nas revistas, na tribuna, as discussões sobre a emancipação feminina geravam polêmicas e apontavam novos espaços os quais as mulheres iriam ocupar no século XX.
\end{abstract}

PaLAVRas-chave: Gênero - Revista - Recife.

\begin{abstract}
In Recife, to build a civilized city, women have become an important part in the construction of a city within the purposes of civilization, so women wereshaped according to the interest of social groups. Knowledge as a common right to the people became a necessary tool for achieving a civilized city. Alongwith this desire for progress, the urban transformations in the city and their consequences modified the profile of women in society. In different historical moments, in the 1800 's, despite of conservative sectors of society in newspapers and magazines, on tribune, the discussions about female emancipation and intellectualization generated controversy and pointed out new spaces which women would occupy in the twentieth century. The literature has incorporated these transformations, and in all literary periods, the novel started to be questioned. In "Emparedada da Rua Nova", the author Carneiro Vilela, born in Pernambuco, engaged this woman of the late nineteenth century and presented a female offender profile for the time, setting for each of these women the absence of the social and moral punishment that they deserved.
\end{abstract}

KeYWORDS: Genre - Literature Novel - Civilization - Recife.

\footnotetext{
${ }^{1}$ Mestranda da Universidade Rural de Pernambuco. E-mail: terezaalbuquerque555@hotmail.com
} 
As inquietações das mulheres e sua notoriedade na sociedade brasileira, mesmo em casos pontuais, surgem desde a Colônia. Personalidades - como as administradoras Ana Pimentel, Brites de Albuquerque; as quilombolas ou líderes de quilombos, como a negra Aqualtune, Filipa Aranha, Teresa de Quariterê, Zeferina, Dandara; as resistentes aos holandeses, como a índia Clara Camarão, Maria Ortiz; as bandeirantes Maria Dias Ferraz do Amaral, Antônia Ribeiro; as emancipacionistas Anita Garibaldi, Bárbara Heliodora, Maria Quitéria; ou as que se tornaram populares, e por isso foram marcadas negativamente como loucas e prostitutas, Chica da Silva, Marília de Dirceu, Dona Beja e outras (TELLES, 1999, p.27) fazem parte do imaginário social, mas, na virada do século XX, sobretudo por causa da urbanização e do afã do progresso, a expressão "feminismo" ganha relevo e conquistas.

A urbanização do Recife pode ter sido singular, mas não única. Pois a modernidade representada por ela se apresenta nas cidades brasileiras revestida de sua face mais comum: a contradição. Se de um lado a cidade buscava, através da normatização e ideologias racionalistas, um status de civilidade, do outro ela mesma convivia com suas próprias mazelas. Paralelamente aos discursos racionalistas, ainda existia uma considerável população escrava, miséria, doenças tropicais e analfabetismo de boa parte dos moradores da cidade. Apesar dessas contradições, pelos ideais de civilidade e pela ciência, as elites intelectuais brasileiras buscaram legitimar suas falas e, ao mesmo tempo, propagar como verdade útil e necessária a ordem e o progresso.

Dentre os discursos nacionalistas e propagadores do progresso, surgiu, não só para as elites como também para o Estado, uma necessidade de legitimar o progresso embasado pela ciência e, por extensão, exaltar a filosofia positivista e racionalista da época. $\mathrm{O}$ caminho encontrado pelas elites e pelo Estado para este fim foi o da "ideologia ilustrada". Propalada como bem comum destinado aos povos, alguns segmentos da sociedade pernambucana, nos seus discursos, colocavam-na como categoria essencial para o progresso: educar para civilizar. A mulher, nesta perspectiva, assume um papel de destaque como educadora da nação.

Para as pesquisadoras Alcileide Cabral e Noêmia Pereira da Luz (2012, p.3), os acontecimentos dos oitocentos, com sua maior urbanização, contribuíram para uma maior possibilidade de mudança dos papeis das mulheres na sociedade. Essas modificações possibilitaram a elas obter ganhos jurídicos, intelectuais e materiais que pouco a pouco delineiam um perfil feminino condizente com o da era da "civilização". Nesse período, alguns elementos foram decisivos para a construção da nova conjuntura republicana, pois eles contribuíram para a formação do quadro da modernidade. A urbanização foi crucial para a formação de novas mentalidades que, por sua vez, implicaram várias questões relacionadas à mulher. No século XIX, a figura feminina fulgura como elemento de discussão e suas ações se tornaram mais públicas.

Nesse contexto, surgem diversas manifestações que traduziam as inquietações de muitas mulheres. Esse desassossego se estende para a posteridade e se traduz num conjunto de reivindicações cuja representação maior era a luta pelo reconhecimento da sociedade de que elas eram sujeitos de direitos; e "o feminismo daquele período esteve intimamente associado a personalidades" (PINTO, 2003, 
p.14), ou seja, as manifestações resultavam, na maioria das vezes, do esforço de mulheres de espírito sutil e revolucionário. Em casos isolados ou não, elas exigiam uma maior igualdade de direitos, dentre eles, o da intelectualização.

\section{Importantes também para a} modificação desse perfil em fins desse período foram os ideais de civilização e progresso que vieram na esteira da teoria positivista da época. Muitas mulheres que defendiam o feminismo no Brasil do século XIX "acreditavam no progresso, e extraíram inspiração e promessa de sucesso futuro das conquistas femininas nos outros países" (HAHNER , 2003, p.172). As inquietações deste período eram constantes ante as novas mentalidades associadas à figura feminina. Por isso, a produção discursiva que se ocupava delas servia ideologicamente a vários propósitos, conforme 0 grupo discursivo que as representava. Esses grupos construíram um modelo de mulher baseado ora na exclusão, ora na inclusão. O que se faz sentir neste período é que, um mínimo de intelectualização, para muitos dirigentes, a mulher deveria ter. Porém, algo que não divergia entre a maioria desses grupos na construção desse modelo é que, de alguma forma, a mulher precisava ser interditada, cerceada e limitada. A prova disto é que os discursos estavam permeados de imperativos determinando como essa mulher deveria se comportar, o que ela deveria ler, como ela deveria se vestir, e até aonde, mesmo quando a emancipação era colocada em pauta, ela deveria chegar.

Apesar das negativas, essa "inspiração e promessa de sucesso futuro" marcam os discursos dos grupos feministas, não só no Brasil, mas também nos países da América Latina. Em revistas, folhetins, romances, os discursos, tanto das mulheres quanto dos homens, a favor ou contra a emancipação, pululavam na consciência social e se constituíam, muitas vezes, em debates profícuos que, de uma forma ou de outra, modificavam as mentalidades culturais da época.

No Recife, a confirmação deste pensamento vem pelo trabalho de uma das mais importantes feministas do país, a cronista, poeta, ensaísta e romancista Nísia Floresta Brasileira Augusta. Era positivista, defendeu a abolição da escravidão, a instauração da República, a educação da mulher. Nascida em 1810, no interior do Rio Grande do Norte, foi uma das primeiras mulheres a romper as barreiras do privado. Sua atuação na imprensa, desde 1830, a favor de uma maior igualdade de direitos entre homens e mulheres, foi fundamental para que, no Brasil, a discussão da emancipação feminina fosse levantada (DUARTE, 2005, p. 5).

No Recife, apesar de os jornais da época abordarem o assunto da emancipação da mulher com mais enlevo no final do século XIX e início do $X X$, a cidade sai na dianteira por ocasião da disseminação dos ideais emancipacionistas da escritora, por isso a atuação dela para a discussão acerca da condição social da mulher representou um ganho para a emancipação em Pernambuco. Ela foi uma das primeiras mulheres em Recife a discutir assuntos como: maternidade, com isso questionava a verdadeira finalidade do ato de ser mãe e de amamentar; a educação da mulher, neste ponto ela defendia a tese de que a mulher intelectualizada estaria apta a exercer funções públicas tanto quanto os homens; a utilidade do homem e da mulher na sociedade, com isso reafirmava o papel preponderante da mulher na construção de uma sociedade civilizada (DUARTE, 2005, p. 5). 


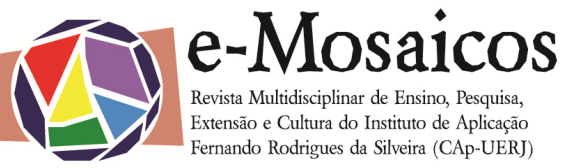

Na cidade, no ano de 1832, o seu livro de cunho emancipacionista, e o primeiro com esse viés "de que se tem notícia no Brasil, foi lançado. Direito das Mulheres e injustiça dos homens surgiu quando a autora tinha vinte e dois anos" (DUARTE, 2005, p. 17) e uma boa parte das mulheres viviam reclusas em seus lares e envoltas em preconceitos. Apesar de Nísia Floresta dizer que se tratava de uma "tradução livre" do livro inglês Vindications of the rights of woman (1792), da feminista Mary Wollstonecraft ${ }^{2}$, o livro representa uma releitura das ideologias emancipacionistas que surgiam na Europa. Fora posteriormente reeditado em 1833, em Porto Alegre e, em 1839, no Rio de Janeiro (DUARTE, 2005, p. 7).

De forma sensível e inteligente, Nísia ressignificou para o país os ideais feministas. A "polifonia" se faz presente no livro de forma contínua através da "intertextualidade" ${ }^{\prime \prime 3}$ subsidiada pelo

\footnotetext{
2 Mary Wollstonecraft, falecida em 1797, foi uma entusiasta das conquistas igualitárias e fraternas da Revolução Francesa de 1789, elaborou a primeira carta do feminismo moderno. Para saber mais, ver http://educaterra.terra.com.br/voltaire/mundo/2004/1 1/08/000.htm, acesso em 15 de junho de 2013.

3 Intertextualidade é a inserção de um outro texto referenciado num texto base. Ela pode acontecer de forma direta, com o texto referenciado entre aspas, ou de forma indireta. Exemplo disto são as paródias. Já o conceito de polifonia - poli = muitos, diversos; fono = som; voz- não se refere apenas a textos. A intertextualidade é a voz materializada (fala e escrita). A polifonia nem sempre é materializada na escrita ou na fala apenas, mas em atitudes e crenças, comportamentos ou negações. No caso do feminismo, quando Nísia não aceita uma condição de exploração, ela reitera um discurso que possui como base um caráter ético, ou seja, pautado numa auto-reflexão do sujeito. Para a literatura, esse recurso é importante para o autor. A intertextualidade seria um diálogo de textos, várias vozes, consoantes ou dissonantes, não neutras, proferidas no discurso. Ela pode ser representada por uma paródia, perífrase, paráfrase, citação. O fenômeno foi estudado pelo teórico da lingua-
}

discurso da inglesa, a feminista afirma seus propósitos. O discurso de outrem seria "o discurso no discurso, a enunciação sobre a enunciação" (BAKHTIN, 1997. p.144), ou seja, falar de feminismo implicava contextualizar o movimento para o interlocutor, sinalizar que a sua incidência em outros países era um fato, e se munir de "autoridade polifônica" ${ }^{4}$ para isto. Esses recursos argumentativos são importantes sempre que o eu se coloca na presença do outro.

Desta forma, nenhuma voz se representa completamente pura, individual. Sempre no seu interior haverá resquícios da presença do outro. Foi o que Nísia Floresta, como uma intelectual que era, fez. Ao contrário do discurso monofônico, autoritário, a polifonia representa a possibilidade de uma luta verbal implícita cultural entre as falas dispostas. Conservando o dialogismo da linguagem, ela marcou uma subjetividade. O sujeito se revelou através da linguagem porque "a palavra é o fenômeno ideológico por excelência. A realidade toda da palavra é absorvida por sua função de signo"

gem Michael Bakhtin, em seu ensaio 'problemas da poética de Dostoieviski'. Ele considera o escritor russo o criador de um novo tipo de romance, o polifônico, dotado de vários tipos de vozes. Para saber mais vide: MARCUSCHI, Luiz Antônio. Produção textual, análise de gêneros e compreensão. São Paulo, Ed. Parábola, 2008.

4 A autoridade polifônica é um recurso de argumento utilizado nos textos, sobretudo argumentativos, com a finalidade de dar maior credibilidade ao discurso retórico e persuasivo. Sua função busca comprovar, no processo de interação verbal, por vozes explícitas, a veracidade ou negação de uma ideia, conceito ou ideologia.

Nesse contexto, a autoridade polifônica pode ser compreendida como uma voz dentro do texto base que serve ao emissor de recurso argumentativo. Para saber mais vide: $\mathrm{KOCH}$, Ingedore Villaça e ELIAS, Vanda Maria. Ler e Escrever: estratégias de produção textual. Ed. Contexto, 2 edição, São Paulo, 2010. 
(BAKHTIN, 1997, p. 37). Daí a importância da linguagem ser vista sempre dentro de uma concepção interacionista, ou seja, deve-se analisar o enunciado inserido num contexto de enunciação. Esta concepção leva em consideração a situação social dos interlocutores, os universos axiológicos desses, elementos espaço-temporais que engendram $o$ ato comunicativo.

Mesmo suavizando as suas convicções, frente à sociedade misógina da época, quando ela escreve que "não tem sido com a intenção de revoltar pessoa alguma de meu sexo contra os homens, nem de transformar a ordem presente das coisas relativamente ao Governo e autoridade" (FLORESTA apud DUARTE, 2005, p. 89-95), Nísia Floresta opera argumentativamente e reafirma os seus ideais, quando diz que uma das origens das desigualdades sociais, civis e políticas entre homens e mulheres reside "na falta de saber e educação, que arrasta as mulheres às ações que os homens reprovam" (FLORESTA apud DUARTE, 2005, p. 89-95).

O teórico Oswald Ducrot, que trabalha na perspectiva de uma Semântica Pragmática ou Pragmática Linguística, desenvolveu a Teoria da Argumentação. Ele partiu do princípio de que a língua não possui somente a função de descrever 0 mundo, mas sim recriá-lo. Dessa forma, para ele, a principal função da linguagem seria a de argumentar. Por isso, para que haja o processo de convencimento, é necessária a participação de enunciadores que interajam a fim de estabelecer um elo comunicativo (DUCRAT apud MOREIRA, 2009, p. 223-231). Esse processo de interação verbal, estabelecido pela alteridade, deve ser entendido como práticas que formam sujeitos, ele se estabelece em todas as esferas sociais, e marca uma atitude política e ideológica dos enunciadores (BAKHTIN, 1997).

Assim,

OS

operadores

argumentativos têm como função mostrar o caminho para o qual a argumentação está direcionada. E o mas, o contraditório, é considerado por Ducrot 0 "operador argumentativo por excelência" (DUCRAT, apud MOREIRA, 2009, p.17). Os mecanismos de oposição estabelecem as direções argumentativas para as quais o texto converge e alicerçam os determinados pontos de vista com os quais o autor constrói seu argumento. 0 operador argumentativo da feminista se pauta na negação, pois tem por finalidade introduzir um argumento plausível para uma determinada conclusão, e, em seguida, colocar um argumento definitivo para a conclusão contrária.

Em muitos dos discursos da época, acerca da condição feminina frente à nova conjuntura que surgia, a negativa fazia parte do processo argumentativo dos que acreditavam na importância da emancipação feminina, como foi o caso de Nísia Floresta, ou dos que reafirmavam os valores misóginos da época, como o Padre Lopes Gama, O Carapuceiro. Contemporâneo da autora, ele confirma os valores sociais da época pela oposição, no seu artigo "As mulheres literatas":

Não sou do número daqueles que, supondo 0 belo sexo incapaz de grandes combinações intelectuais, ousam dizer que o maior talento de uma mulher apenas chega para arrumarem baú de roupas. Ainda que eu quisesse abraçar esta opinião, que é mais um epigrama que outra coisa, a história das nações e minha própria observação me convenceriam do contrário. A Grécia teve suas Aspásias e a França... a espantosa Madame Stael. Todavia, forçoso é confessar que, no belo sexo, o que mais 
predomina é a imaginação e, conseguintemente, falando em geral, as mulheres são mais aptas para as belas letras do que para as ciências (...). Elas se aborrecem de tudo quanto demanda grande esforço da razão (MELO, 1996, p. 361).

Por isso, era difícil para uma mulher se posicionar sobre questões "tão delicadas" numa sociedade cuja herança colonial era misógina. Nesse contexto, a lógica que perdurava era a de que o homem possuía status quo e deveria representar o dominus, 'Senhor' de tudo e de todos; a mulher deveria ser apenas 0 apêndice dele (ALMEIDA, 2003, p. 90). A ela, o espaço da razão era negado, o pensamento do padre corrobora para as conclusões da historiadora Marta Abreu (ESTEVES, 1989, p.46) quando reafirma que, na sociedade oitocentista, o ideal de mulher, para a maioria dos homens do período, é aquele pautado não só na submissão, mas na sensibilidade, arte, lar, castidade, decoro, honra.

Os pensamentos de Nísia eram "subversivos" para a época e a consequência dessa afronta foi, por muitos anos, o não reconhecimento social. A obra dela foi relegada a um segundo plano e o seu nome fora esquecido na literatura brasileira, até o momento em que seus textos foram revisados no século $X X$. Por isso, negar o processo de emancipação, no caso de Nísia Floresta, era apenas uma forma da autora, munida de argumentos filosóficos- "como o ideal de dignidade e o valor do ser humano, a moral, a razão, a virtude" (FLORESTA apud DUARTE, 2005, p. 22) - reafirmar os direitos das mulheres e denunciar uma situação de exploração.

Uma grande atuação dela para a discussão e luta dos direitos das mulheres é encontrada na sua produção jornalística. Em alguns dos periódicos do Recife, Floresta inicia a sua carreira literária. Dentre eles destacamos 0 jornal de variedades (1827), O relator de novelas (1836), o Espelho das brasileiras (1831) (DUARTE, 2005, p. 20). Anonimamente, em meados do século XIX, pioneiras do jornalismo feminino em Pernambuco fizeram deste suporte de comunicação um instrumento de resistência, ou um espaço da veiculação de pensamentos, opiniões e conjecturas de muitas mulheres do período.

O jornal representava não só um espaço de discussão dos grandes fatos ocorridos na cidade e no mundo, mas ele denuncia sensibilidades de um tempo. Conforme o pensamento dos idealizadores, eles marcam posições políticas e culturais. E a expressão feminismo começa a ganhar destaque na sociedade no final do século XIX. A Légende de La femme émancipée, ou seja, a expressão "emancipação feminina", era usada nos jornais recifenses, e esse processo de transplantação influenciou as ideias emancipacionistas na América Latina e consequentemente no Brasil.

Muitos textos eram traduzidos, ou as traduções das publicações de livros que tratavam dessa temática eram anunciadas. Nos jornais, femininos ou não na cidade, a discussão sobre a emancipação da mulher começa a ganhar força. Nesse processo de emancipação, as influencias estrangeiras se constituíam base essencial para que a luta pela igualdade de direitos das mulheres tivesse força e voz. Com base nas relações de alteridade, o local e o global, ou vice e versa, novas mentalidades sobre a mulher foram incorporadas.

Por uma nota, houve a divulgação da publicação do livro Légende de La femme émancipée, da escritora feminista francesa Firmin Maillard, "LITERATURA: O livro de 
Firmin Maillard que a pouco apareceu com o título Légende de La femme émancipée tem causado e há de continuar grande sensação no campo das emancipadoras e dos defensores dos direitos políticos da mulher" (DIÁRIO DE PERNAMBUCO 1, 1887, p. 4). Uma pequena tradução de um trecho do texto já mostra o quanto as ideias contidas nele eram avançada para época. Extraído da 'constituição das Vesuvianas':

As cidadãs deverão formar um contingente para o exército de terra e mar... As recrutas formarão um exército designado como reserva, que será distribuído em três divisões: a das operárias, a das vivandeiras, a de caridade... Sendo o casamento uma associação, cada um dos dois esposos deve participar de todos os trabalhos. Todo marido que se recusar fazer a sua parte nos cuidados domésticos será condenado... a assumir, em vez de seu serviço pessoal na Garde Nationale, o serviço de sua mulher na Guarda Cívica (MAILLARD, 1886, p. 179).

Por isso, para muitos, a emancipação deveria ser combatida. Já outros buscavam entender 0 sentido dela frente às transformações ocorridas na cidade.

Jornais destinados às mulheres, ou escritos por elas, denunciam força, subversão, reflexão e/ou receio, medo, e por vezes, culpa, nas letras de muitas mulheres. No Jornal Pequeno, iniciou-se "a publicação periódica de uns escriptos sob o título acima (cartas femininas), devidos à pena de uma intelligente litterata Pernambucana" (JORNAL PEQUENO 1, 1901, p. 1$)^{5}$.

\footnotetext{
${ }^{5}$ Anúncio do jornal sobre o início de uma coluna assinada pela colaboradora Maria do Carmo.
}

CARTAS FEMININAS- Querida Lúcia. Devido a obsequiosidade dos illustres redactores do 'Jornal Pequeno', enceto hoje nas collunas dessa apreciada folha uma despretenciosa serie de cartas, endereçadas a $t i, e$ nas quais me proporei expender minha desautorisada opinião sobre qualquer assumpto dizendo francamente o que sinto e penso de tudo e de todos.

Antes, convém declarar que não sou partidário da emancipação da mulher, cuja missão ao meu ver, deve unicamente circunscrever-se ao lar, embora desse santuário de paz e amor tenhamos o direito e mesmo o dever de nos inteirarmos do que se passa no exterior, no mundo official, em fim [...]

Compreendes que eu tenho necessidade de publicar minhas opiniões nesse sentido, para não ser levada a conta de uma revolucionária, que manejando a pena, procure incutir, no ânimo de minhas leitoras, uma revolta infructifera e de encontro à sublime harmonia em que o supremo criador estabeleceu todos os seres e todos os factos da natureza. Grifo Nosso

Perceba que o texto é permeado por ambiguidades e, ao que parece, sinaliza que as discussões da emancipação da mulher eram, na sociedade e nos jornais, algo comum, mas muita diferença fazia ser ou não partidário da questão. A nossa "ilustre" Maria do Carmo não pretende ser entusiasta da emancipação feminina, diz que a missão da mulher deveria apenas se "circunscrever ao lar". No entanto, ela não abre mão de expor no jornal, veículo público, sua opinião sobre "qualquer assumpto". O que ocorria é que a inquietude da questão colocava, por vezes, muitas mulheres na defensiva, ao ponto de quando começarem as suas falas, numa sociedade em que as discussões 
sobre emancipação estavam acirradas, elas seriam sugestionadas a tomarem uma posição. Vê-se que o debate sobre a emancipação não surgira apenas no final do século XIX, mas crescia na medida em que as mulheres iam ganhando mais espaços na sociedade. No mesmo jornal no mês de setembro se postava:

NA INGLATERRA. Os partidários da emancipação da mulher sofrerão uma perda talvez irreparável com a morte de Dr. Beach decano dos deputados na câmara communs. O senhor Beach era um defensor ardente e infatigável dos direitos políticos da mulher votando sempre a favor das leis que visa tal fim (JORNAL PEQUENO 2, 1901, p. 1).

Pelo discurso, os rumores de emancipação em Recife era um fato. E, porventura, se essa discussão não tomava grandes proporções nos principais jornais da época, nos destinados à mulher, essa questão era mote de muitos debates; e as colaboradoras de jornais já emitiam sua opinião, ora exaltando os valores femininos, ora restringindo as atividades da mulher ao âmbito privado. O jornal O Beija Flor $^{6}$ já em

\footnotetext{
${ }^{6}$ Segundo Luiz Nascimento, "O BEIJA-FLOR - Jornal Dedicado às Senhoras - Entrou em circulação a 19 de junho de 1880 , formato de $22 \times 16$, com quatro páginas a duas boas colunas de composição, sendo impresso em papel especial, na Tip. Acadêmica, a rua Duque de Caxias $n^{\circ} 18$. Órgão essencialmente literário, embora prometesse ocupar-se de tudo, deu a público o $\mathrm{n}^{\circ} 2$ no dia 10 de julho, não mais aparecendo. Prometera, em artigo de apresentação,proporcionar boa leitura, indo "procurar os escritos mais belos" para "encantar" as leitoras. Nas duas edições divulgadas, 0 Beija-Flor inseriu comentários locais e crônicas intituladas "O Riso", "As flores", "Os romances", "A mulher", etc., esta última a continuar num terceiro número. Nenhuma matéria, todavia, nem mesmo o único poeminha, teve assinatura. Redação, igualmente,desconhecida". Para saber mais vide: http://www.fundaj.gov.br/geral/200anosda imprensa/historia_da_imprensa_v06.pdf, acesso em
}

1880, na sua primeira edição, se mostra preocupado com tais querelas e nos mostra que a questão da emancipação gerava, em muitos segmentos sociais, um desconforto, por isso, dissipar esta ideia parecia ser a melhor coisa a fazer.

\begin{abstract}
A MULHER. Senhora leitora, se há um assumpto que deva merecer vosso interesse, prende a vossa atenção; se há ahi uma questão que o Beija Flor não pode deixar de dar-vos a sua opinião, é sem dúvida essa que diz respeito ao logar que ocupaes na família, a missão que tendes na sociedade, a vossa condição social. Há ahi muita gente, belas leitoras que fazendo uma ideia errônea da importância de vossa posição, pretende melhorar 0 vosso estado, despreendendo-vos do seio familiar, e atirando-vos no meio da sociedade, para ahi lutardes face a face com o homem. É a isso que vulgarmente se chama de vossa EMANCIPAÇÃO, como se fosseis escravas, onde sois senhoras, como se fosseis servas onde sois rainhas.[...]. Algumas senhoras há com efeito que entregando-se as impressões de ligeiras leituras, deixamse illudir por esse modo extravagante de pensar e sem perceber o mal que causam a si próprias afagam igualmente essa ideia perniciosa.
\end{abstract}

Aqui mesmo na cidade, não há muito tempo, encontrei-me em um salão com uma senhora que, fazendo muito de propósito rolar a conversação sobre esse assunpto defendia a ideia de vossa chamada emancipação com tão profunda convicção, com tamanho ardor, que a todos levava a palma, porém, seja dito de passagem, mais pela delicadeza que o vosso sexo se deve, do que por força de suas razões.Não obstante, porém, é de notar que esta ideia extravagante tem

12 de maio de 2013. 
entre os homens maior número de advogados que em vos mesmas. Mas esses que se intitulam vossos defensores, querendo confundir com a nossa a vossa missão, querendo estabelecer entre ambos os sexos uma igualdade impossível, contra a qual protestão a índole e a natureza de cada uma, esses convencei-vos são os que mais compromettem a vossa causa.[...] (O BEIJA FLOR, 1880, p. 1). Grifo Nosso

Pelo discurso da redatora, duas coisas merecem ser destacadas: a primeira, o fato de num salão uma senhora discutir o assunto, e o mais interessante, ser "aplaudida" por demais; a segunda é a participação e anuência de alguns homens nas questões dos direitos relativos às mulheres. Provavelmente, a "nobre colaboradora" estava falando de alguns entusiastas do progresso e civilização em Pernambuco que defendiam uma nova postura da mulher frente ao ideal de progresso, atribuindo a elas responsabilidades na consecução de uma nação civilizada. As relações ambíguas no discurso da redatora são latentes, com o intuito de fortalecer o pensamento cultural de que o espaço da mulher deve se circunscrever ao lar, o discurso da redatora representava também uma tendência da época: havia mulheres tão misóginas quanto os homens. O discurso do Eterno Feminino se faz valer na voz dela. A circunscrição do trabalho e dever da mulher na esfera privada, em detrimento à esfera pública, constitui o argumento primeiro da redatora. Por fim, ela reafirma o que muitos farão na sociedade brasileira e recifense dos oitocentos: Uma relação de igualdade de direitos entre os gêneros seria impossível.

Desse modo, frente às novas mentalidades e à nova conjuntura política e social da cidade, as aspirações de emancipações na sociedade foram muitas vezes frustradas pela manipulação do discurso científico passadista que servia como legitimador da inferioridade da mulher. Essa divisão de gênero baseada na diferença de sexo, sobretudo pela anatomia do corpo e pela divisão social do trabalho, foi construída historicamente e justificada como um processo "natural" pautado na bipolarização: alto/baixo, público/privado, sair/entrar, subir/descer. Diferença cujo parâmetro foi o homem, e deixou como consequência o mito do Eterno Masculino e Eterno Feminino, marcado antes de tudo pela androgenia (BOURDIEU, 1989, p. 39) e "a ideia de gênero, enquanto categoria relacional, histórica e uma perspectiva de análise, permite compreender o processo de construção social da mulher fundamentado nas diferenças sexuais" (SCOTT, 1996, p. 15) percebidas pelo cruzamento dos antagonismos verificados acima.

Essa construção e normatização do gênero reforçava, na sociedade, um discurso de fragilidade, docilidade, inferioridade intelectual das mulheres, propagado por todo o período colonial. No todo, o que se faz sentir é um caráter não gratuito da necessidade da mudança do perfil da mulher propagada por alguns intelectuais em busca do progresso, ou até pela Igreja, quando, por ocasião da declaração de Dom José Joaquim da Cunha de Azeredo Coutinho, bispo de Pernambuco, na virada do século XIX, contrariando a lógica dos que não viam com bons olhos a intelectualização feminina, afirma a necessidade, para a família e a $\mathrm{Na}$ ção, da instrução feminina, desde que seja na medida certa (HAHNER , 2003, p. 107).

Pelas condicionais proferidas, a muIher precisaria pagar um ônus por um maior conhecimento e por pequenas concessões jurídicas e sociais. Por isso a intelectualização e sua "emancipação" se deu de forma 
lenta e gradativa e, o mais importante para a mentalidade misógina do período, restrita: num primeiro momento ao âmbito privado; no segundo, ao espaço público. Pois cabia a elas educarem não só os filhos da pátria, mas também os seus próprios filhos. As mulheres, sobretudo das elites, eram responsáveis pela formação moral dos cidadãos capacitados para ocuparem os cargos dirigentes do país. As populares cumpriam também sua função nesta nova conjuntura social que se afirmava na nação, cabia a elas a docência não só no âmbito familiar, mas também no público. Essas mulheres precisavam se diplomar no saber e, consequentemente, garantir o seu sustento e o da sua família, através de um "ato nobre", al- fabetizar as crianças (NAGLE, 2001, p. 68).

Essas representações da ideia de emancipação da mulher em Recife não se restringiram apenas ao discurso escrito, ao que parece o apelo da colaboradora d'O Beija-Flor não foi no todo atendido. Pelo humor, através da imagem, muito da modificação do perfil da mulher na sociedade oitocentista seria anunciado, dois anos depois da ressalva e orientação da colaboradora do jornal feminino, de forma irônica o jornal humorístico, Lanterna Mágica, prenunciava para o futuro qual seria o espaço da mulher e qual seria o espaço do homem na nossa sociedade.

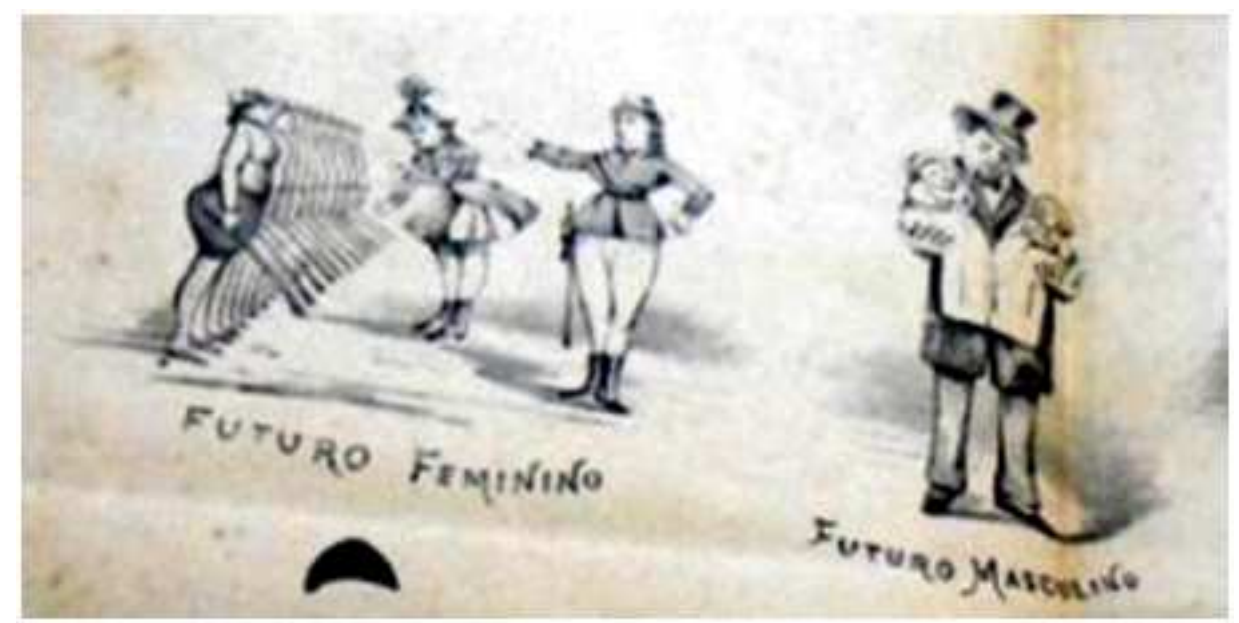

Fig. 1 - Charge publicada no ano de 1882

Fonte: APEJE- Lanterna Mágica, n 6 - ano 7. Recife, 20 de março de 1882.

Com maior ou menor tiragem do jornal, muitos discutiam a questão da emancipação, até mesmo aqueles com alguns fins específicos, como a campanha abolicionista, possuem na sua redação um toque de discussão acerca da importância da mulher para a sociedade, que não seja propriamente a procriação e o lar. O Ave
Libertas cuja diretora é a modista Leonor Porto ${ }^{7}$, nas suas edições, mostra-nos isso,

\footnotetext{
${ }^{7}$ Leonor Porto nasceu em Pernambuco, por volta da segunda metade do século XIX. Ela exerceu as funções de costureira, era uma das mais importantes modistas da época em Recife. Por ocasião da campanha abolicionista, se associou ao clube do cupim, que angariava fundos para a causa da abolição, posteri-
} 
quando a colaboradora Carlota Alves compara as nossas abolicionistas a "Charlot Corday, com uma punhalada fazendo correr o sangue do peito de Marat; ou como Joana Darc salvando Orleans" (AVE LIBERTAS 1, 1885 , p. 2.). Se quisermos ir mais adiante, encontraremos no mesmo jornal, agora no ano de 1886, uma voz, a da colaboradora Ismenia Maria Duarte Pinheiro. Consciente do papel da mulher na sociedade, ela nos aponta um certo "dever" da mulher. Apesar do título do artigo ser o abolicionismo e nele essa matéria ser tratada, transparece no discurso qual o papel que a mulher deveria exercer na sociedade:

\begin{abstract}
ABOLICIONISMO. Em todas as conquistas do progresso e da liberdade a mulher tem tomado uma parte bem saliente nos seus destinos. Quando a Revolução Francesa de 1789 estendeu aos cinco ventos do universo a sua bandeira, a mulher dava exuberantes provas de que foi predestinada para as grandes luctas sociaes, para o futuro da democracia moderna [...] (AVE LIBERTAS 2, 1886, p. 3). Grifo nosso.
\end{abstract}

Essa anuência ou não nos jornais à causa das mulheres dependia também de qual suporte o texto era veiculado. No período, o Diário de Pernambuco, por exemplo, por ser um jornal tradicional, em muitos dos artigos coletados, não parecia ver com bons olhos a discussão da emancipação feminina, ou ganhos obtidos por algumas mulheres em outros países. 0 que permitia o jornal se apresentar tão contrário ao feminismo? Primeiro, o público a qual se destinava o periódico; segundo, suas posições ideológicas; terceiro, a ideologia dos seus redatores. Observe no

ormente fundou a associação Ave Libertas, morreu em 1906. Fonte http://www2.secmulher.pe.gov.br/ web/secretaria-da-mulher/mulher12 acesso em 25 de junho de 2013.
Diário de Pernambuco a seguinte tradução do Jornal The Graphic de Nova York, por ocasião das eleições municipais de Nova York:

\begin{abstract}
AS MULHERES.
As mulheres: The Graphic de Nova York publicou o seguinte: respeitáveis correspondentes nossos nos participam que em Witchita (Kansas) as mulheres se portaram como verdadeiros cocheiros nas últimas eleições.
\end{abstract}

Em Leavenworth, povoação daquele estado, as mulheres sob a direção de uma tal Golgar, uma das mais proeminentes agitadoras do sufrágio mulheril, naquella terra, travaram a luta eleitoral, pondo em acção os meios mais vis e desprezíveis, envolvendo em suas intrigas muitas das mais respeitáveis senhoras da primeira sociedade, daquela terra, guardando muito pouco decoro a decência nos ataques a pessoas que estavam muito superiores a essas agitadoras em conceito, bondade e pureza, como um anjo está acima da mulher impura.

O homem que desta maneira se conduzisse talvez fosse amarrado à cauda de um cavallo ou enforcado em uma árvore; a mulher que assim procede dá um brilhante e particular exemplo das virtudes daquela população feminina. $O$ pior de tudo é que o sulfragio mulheriu foi ensaiado no estado de Kansas, e agora tornouse indispensável (DIÁRIO DE PERNAMBUCO 2, 1887, p. 3). Grifo nosso.

Apesar de ser uma tradução, o texto busca desqualificar a mulher e sua vitória nas eleições. Até porque não sabemos até onde o artigo foi corrompido ou não, o fato que as expressões linguísticas utilizadas pelo tradutor, como 'agitadoras, uma tal, meios 
vis e desprezíveis', são marcas visíveis que nos apontam uma questão de gênero: a perplexidade de muitos homens, cuja representação política na sociedade era uma constante, em ver uma mulher representar e ser representada na sociedade. Para os homens aceitarem a participação política da mulher no sufrágio elegendo os candidatos já era difícil, imagine-as como representantes dos municípios. Possivelmente 0 tradutor "aumentou um ponto neste conto". Na sociedade da época, o texto representa um produto das dissonâncias do período, quando o assunto era emancipação.

Caso curioso em Recife é o da redatora d'O Lyrio, Maria Augusta Meira de Vasconcelos, aos dezessete anos em 1889, foi laureada, concluiu o curso de Direito e exigia a possibilidade de sua atuação no mundo jurídico. As suas atitudes a punham na sociedade da época como uma mulher emancipada. Por isso, travou várias batalhas e polêmicas nos periódicos da cidade. Sua petição chegou até a atual Ordem dos Advogados, por sua atuação intempestiva. Escreve para o jornal artigos que versam sobre corrupção e a denúncia das mazelas da cidade (FERREIRA, 2005, p. 125). O fato inusitado, apesar de malogrado, é quando ela, uma das poucas vozes no período, em jornal, publica o seu desejo de se candidatar a deputada:

Tenho em mente ser candidata à próxima eleição e desde já apresento aos meus bons patrícios os protestos de minha eterna gratidão pelos sufrágios que para este fim me houverem de prestar, certos de que hei de me esforçar pela prosperidade, deste país, principalmente desta minha terra natal o quanto em mim couber (MARIA AUGUSTA apud GONÇALVES, 2005, p. 127).
As solicitações - nas tribunas, nas instituições, no governo, nos jornais - de mulheres como Maria Augusta, alimentavam na sociedade recifense 0 desejo de emancipação feminina. As ações mais públicas do que privadas dessas mulheres despontariam a condição feminina encontrada nos séculos vindouros. Por vezes, a soma desses discursos se revestia de um maior conhecimento por parte de quem o fazia, mostrando, mesmo por meio da tradução de outros textos, que o movimento ganhava força e se pautava na razão. Feministas como E Sanchez, em seu texto FEMINISMO: versão Chilena, traduzido no Jornal Pequeno em 1901, já respondia ao público recifense o que seria o feminismo.

Que é o feminismo? O que pretende? Nada mais que a igualdade perante a lei para o homem e para a mulher. A Mulher médico! A mulher advogado! A mulher ministro! A mulher deputado! Não pode ser. Então, ela replica. E porque se admite a mulher rainha? A Espanha, a Holanda, China, e até pouco tempo a Inglaterra colocaram muIheres à frente dos seus destinos públicos; o que quer dizer que, ao alvorecer do século $X X$, os homens, em maioria eram súbditos de senhoras. Por que então aquela que serve para rainha não póde ser alcaide? Como exemplos da sua aptidão para a vida pública citam a Suécia onde as mulheres votam nas eleições municipais, e são vogais das juntas locais de instrução; os Estados -Unidos, onde existem comunas em que, ellas exercem direitos políticos. [...]. O que há a averiguar é se a administração municipal da Suécia é peior do que n'outros paizes. Supõe-se que não. $O$ maravilhoso no feminismo é o que fez em favor do progresso intelectual da mulher [...] (JORNAL PEQUENO 3, 1901, p. 4). Grifo nosso. 
As perguntas retóricas utilizadas pela autora, ao mesmo tempo em que instigam o leitor, denunciam o conflito de vozes dissonantes que se passava não só na cidade mas também no país, quando o assunto era a emancipação da mulher. A resposta a essas mesmas indagações serve de mote para a afirmativa das muitas reivindicações das mulheres no período como: equidade de direitos entre os gêneros e o progresso intelectual. Observe que, naquilo que ainda tange a questão das decisões políticas negadas a elas, a analogia acima formada mostra que como rainhas podem governar a nação, cabia também às mulheres decidirem sobre o destino público do país.

O princípio fundante deste pensamento é impulsionado não só pelos novos paradigmas trazidos pela urbanização ocorrida nas principais cidades dos países latino-americanos, mas por toda uma lógica baseada na comparação da situação da mulher latina com as de outros países onde o feminismo ganhou notoriedade. Esta é uma marca recorrente nos discursos sobre o feminismo analisados neste trabalho. Neles, percebemos que a crença dos ideais emancipacionistas na América Latina sofreu forte influência dos países europeus e norteamericanos, sobretudo no final do século XIX, mas isso não representou apenas uma simples transplantação cultural, o fenômeno do feminismo atinge muitos países em todo o mundo. É feliz o pensamento da historiadora Maria Joana Pedro (2011, p. 272), quando diz que o processo de emancipação na América Latina, bem antes da década de 1980, ocorreu de forma simultânea, pois várias reivindicações sociais e políticas ecoaram do continente.

Em cidades brasileiras, como o Recife, pela boca de algumas mulheres e entusiastas da emancipação da mulher, ainda na primeira metade do século XIX, sussurros emancipacionistas já podiam ser ouvidos no Nordeste, como foi o caso de Nísia Floresta e, posteriormente, Amélia de Freitas Bevilácqua ${ }^{8}$. Essa análise nos autoriza a concordar com a historiadora: o feminismo não se deu de forma estanque, isolada, ou como "ondas", ou seja, de um centro irradiador para áreas periféricas, sempre atrasadas em relação ao referente primeiro. Possibilita-nos, sim, a refletir que a crença da origem de um mito fundador desse movimento deve ser questionada, se não, revista. Pois, ao longo da história, muitas foram as mulheres, mas semelhantes também foram as opressões.

Em diferentes países do Cone Sul, a História das Mulheres, além das coletâneas já mencionadas, encontra-se em diversas temporalidades, nunca seguindo as marcas temporais das "ondas", nem mesmo com atraso. Na verdade, em um mesmo período encontram-se discussões historiográficas que partem da categoria "mulher" e da categoria "mulheres", indistintamente. Assim como no Brasil, várias profissionais, oriundas da Sociologia, da Antropologia, da área da Literatura, escrevem sobre a História das Mulheres, não se constituindo, portanto, numa tarefa unicamente de historiadoras (PEDRO, 2011, p. 272).

A mulher foi impulsionada de diversas maneiras pela urbanização a favor de ações cada vez mais públicas, dentre elas destacam-se aspectos de capacitação inte-

\footnotetext{
${ }^{8}$ A redatora-chefe da primeira revista feminina do nordeste, que circulou por dois anos, até o inicio do séc. XX. Amélia de Freitas Bevilaqua defendia a educação das mulheres e a igualdade de direitos. Para saber mais vide: MENESES, Maia Luiza Mota de. Amélia de Freitas Bevilaqua. Fortaleza, Ed. Henriqueta Galeno, 1982.
} 
lectual e profissional. Sofrendo influência dos "ideais ilustrados" da Europa, o modelo de civilização propalado pelas elites locais não poderia se afastar do saber. A Instrução representaria para a sociedade o principal caminho para o progresso material, cultural e intelectual dos povos, ela sedimentaria o projeto de civilização nos trópicos. Nesse contexto, a mulher foi aos poucos angariando espaços e Nesse contexto, o mercado de trabalho e a intelectualização exigiam uma nova postura social da mulher e as ações delas deveriam ir além do espaço privado. Por isso, a educação formal para mulheres passou por importantes mudanças, especialmente no final do século XIX.

Apesar do afã do progresso, os nossos intelectuais não fugiram à regra da estereotipização nesta sociedade civilizada, na qual os papeis entre homens e mulheres foram socialmente marcados e historicamente construídos. Elas deviam ser "professorinhas", "mães" e "esposas". Conforme Carvalho, o símbolo ideal nessa sociedade racionalista era a mulher, cujo mito perfeito seria a virgem-mãe, por sugerir uma humanidade capaz de se reproduzir sem a interferência externa (CARVALHO, 2001, p. 81).

De uma forma geral, as mulheres atendiam aos interesses republicanos e positivistas. No imaginário social, assim como a República, representada em muitas charges do período, e posterior a ele, como uma mulher jovem que deveria guiar o país para o progresso e a civilização, as nossas muIheres, elemento essencial para a manutenção do lar, da ordem e da educação, cumpriam o mesmo papel, mas não mais representado pela monarquia: uma senhora idosa, fraca e experiente; e sim uma mulher jovem, forte e letrada. Observe o desdobramento disso na capa da revista Fon Fon do ano de 1913.

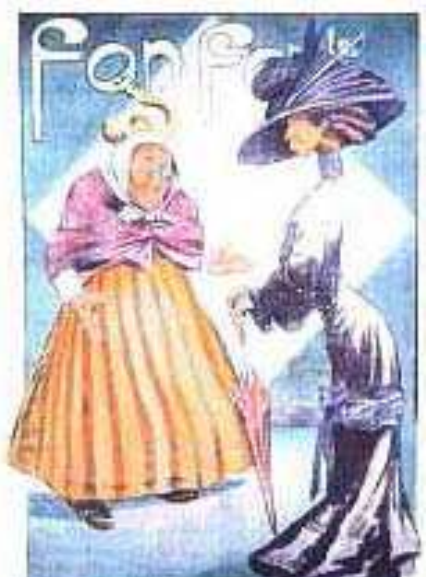

Fig. 2: A capa da Revista Fon - Fon de novembro de 1913.

Fonte: http://professor.bio.br/historia/ provas_questoes.asp?section $=$ Brasil\&curpage $=$ 184.

Para o grupo liberal, pautado no progresso, representado, por exemplo, pelos mais ilustres intelectuais da Escola do Recife, essa mulher deveria se intelectualizar para colaborar com o projeto de civilização. A ela cabia uma função pedagógica: educar os filhos e orientá-los, por meio da ilustração, a construir uma nação forte e civilizada (GATI, 2010, p. 13). Para os conservadores, monarquistas e tradicionais, ela deveria se revestir de uma ideologia cristã, cujo modelo de virtude era o mariano, pautado no silêncio, na submissão e no recolhimento. Mas essa construção, mesmo fundada na dominação, abriu precedentes importantes à mulher. $\mathrm{O}$ primeiro deles foi o acesso à educação.

Por isso, o esforço de algumas associações civis na luta pela propagação do saber. Em Recife, por exemplo, criou-se a Escola Normal para Senhoras da Sociedade Propagadora ${ }^{9}$, e a especificidade técnica das

${ }^{9}$ Uma maior inserção da mulher pobre no magistério ocorreu, sobretudo, no final do século XIX, a partir da 


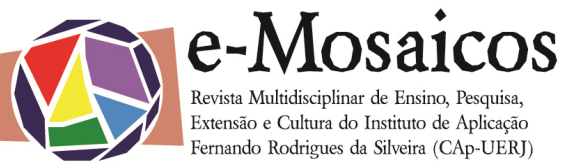

classes populares, pela criação dos Liceus de arte e ofícios. O ideal civilizador cumpria um duplo papel sócio-moralizante: levar o saber "a todas as criaturas" e civilizar a "Nação bárbara". Imbuídos destes projetos, dirigentes da cidade e alguns intelectuais dormiam "o sono dos justos".

\section{CONCLUSÃo}

Em muitas capitais do país, vários questionamentos e críticas aos modelos importados irão surgir, sobretudo quando as novas mentalidades nesse fin de siècle entram em dissonância com as ideologias aristocráticas e burguesas de um país que vivenciava um período de transição política (1870) ou recém- republicano (1909). As contradições podem ser sentidas, quando a população, através de denúncias e/ou opiniões, contrapõe um Recife anterior aos adventos e símbolos da modernidade. As discussões do período também colocam em pauta qual seria o perfil de mulher ideal para essa conjuntura e a emancipação da mulher começa a ser rechaçada, mas também discutida.

No processo de coexistência do moderno e tradicional, a mulher, nesse meio termo, ia aos poucos se modificando, atendendo a uma lógica de progresso exigida por setores da sociedade. $O$ país se dividia, muitos temas eram discutidos, e, quando eram polêmicos para a época, como a emancipação da mulher, criava-se um burburinho em torno dele, então a mulher e sua representatividade na sociedade se

criação, em 1873, no Recife, da Escola Normal para Senhoras da Sociedade Propagadora. Era uma escola privada, mas gratuita, surgida na sociedade civil. Tinha como principal objetivo inserir a mulher no mercado de trabalho, através do exercício do magistério, atividade para a qual, acreditava-se, ela estava destinada. constituía não só material de debate e controvérsias, mas principalmente era revestida por toda uma simbologia cuja construção do mito atendia a vários setores sociais, desde a aristocracia conservadora até a elite progressista.

\section{REFERÊNCIAS BIBLIOGRÁFICAS:}

ALMEIDA, Suely Creusa Cordeiro de. 0 sexo devoto: Normatização e resistência feminina no império português - XVI ao XVIII. Tese (Doutorado em História). Recife: CFCH/UFPE, 2003

AVE LIBERTAS 1. Recife. 4 de setembro de 1885.

AVE LIBERTAS 2. Recife. 8 de setembro de 1886.

BAKHTIN, Mikhail. Marxismo e Filosofia da Linguagem: Problemas fundamentais do método sociológico na Ciência da Linguagem. São Paulo: Ed. Hucitec, 1997.

BAKHTIN. Mikhail. Questões de Literatura e estética: a teoria do Romance. Trad. BERNADINI, Aurora. 4. ed. São Paulo: Ed. UNESP, 1998.

DIÁRIO DE PERNAMBUCO 1. Recife. 22 de setembro de 1887, n. 215.

DIÁRIO DE PERNAMBUCO 2. Recife. 22 de dezembro de 1887, n. 270.

DUARTE, Constância Lima. Nísia Floresta: a primeira feminista do Brasil. Florianópolis: Ed. Mulheres, 2005.

ESTEVES, Martha Abreu. Meninas Perdidas: os populares e o cotidiano do amor no Rio de Janeiro da Belle Epoque. Rio de Janeiro: Ed. Paz e Terra, 1989. 


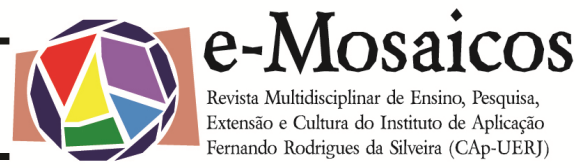

FERREIRA, Luzilá. Maria Augusta Meira de Vasconcelos: biógrafa, poetisa, jornalista, professora. Advogada não. In A escritura da nova mulher. ORG Luzilá Gonçalves, Programa de Pós-graduação em Letras, Recife, UFPE, 2005.

FLORESTA, Nisia. Direito das Mulheres e injustiça dos homens. $4^{a}$ edição. Ed. Cortez. P89-95 In: DUARTE, Constância Lima. Op. Cit, 2005.

HAHNER, June Edith. Emancipação do sexo feminino: a luta pelos direitos da mulher no Brasil(1850-1940). Ed. Mulheres. Santa Cruz do Sul: EDUNISC, 2003.

JORNAL PEQUENO 1. Recife, 2 de agosto de 1901, n. 158.

JORNAL PEQUENO 2. Recife, 26 de setembro de 1901, n. 218.

JORNAL PEQUENO 3. Recife, 28 de novembro de 1901, n. 287.

$\mathrm{KOCH}$, Ingedore Villaça e ELIAS, Vanda Maria. Ler e Escrever: estratégias de produção textual. São Paulo: Ed. Contexto, 2 edição, 2010.

MAILLARD, Firmin. La Legende de La Femme Emancipée, Paris, 1886 p.179 apud fonte: http://arquivoswbdeantropolo gia.net.br/dispositivo-wb-de-antropologia/pmaterialismo-antropologico-historia-dasseitas/, acesso em 23 de outubro de 2013.

MARCUSCHI, Luiz Antônio. Produção textual, análise de gêneros e compreensão. São Paulo: Ed. Parábola, 2008.

MELO, José Antônio Gonçalves de. Diário de Pernambuco: Economia e Sociedade no Segundo Reinado. Recife: Ed. Da UFPE, 1996. p. 361.
MENESES, Maia Luiza Mota de. Amélia de Freitas Bevilaqua. Fortaleza: Ed. Henriqueta Galeno, 1982.

MOREIRA, Tatiane Aparecida. O operador argumentativo mas em duas canções: mas que parada é essa? Revista interdisciplinar Ano IV, V.8, jan-jun de 2009 - ISSN 1980-8879 | p. 223-231.

NASCIMENTO, Alcileide Cabral e LUZ, Noemia Maria Queiroz Pereira. Liberdade, Transgressão e Trabalho: cotidiano das mulheres na Cidade do Recife (1870-1914).

Revista Territórios e fronteiras. Cuiabá, V.5, n1, jan-jul, 2012.

O BEIJA FLOR.. Recife. 10 de julho de 1880, n. 2.

PEDRO, Joana Maria. Relações de Gênero como categoria transversal na historiografia contemporânea. Topoi, v. 12, n. 22, jan.-jun. 2011

PINTO, Celi Regina Jardim. Uma história do feminismo no Brasil. São Paulo: Ed. Fundação Perseu Abramo, 2003.

TELES, Maria Amélia de Almeida. Breve História do Feminismo no Brasil. São Paulo, Ed. Brasiliense,1999.

http://www.fundaj.gov.br/geral/200anosdai mprensa/historia_da_imprensa_v06.pdf acesso em 12 de maio de 2013.

http://arquivoswbdeantropologia.net.br/disp ositivo-wb-de-antropologia/p-materialismoantropologico-historia-das-seitas/, acesso em 23 de outubro de 2013.

http://educaterra.terra.com.br/voltaire/mun do/2004/11/08/000.htm, acesso em 15 de junho de 2013. 